The Frodo Franchise 
The publisher gratefully acknowledges the generous contribution to this book provided by the General Endowment Fund of the University of California Press Foundation. 


\section{The Frodo Franchise}

The Lord of the Rings

and Modern Hollywood

KRISTIN THOMPSON

甲

UNIVERSITY OF CALIFORNIA PRESS

BERKELE LOS ANGELES LONDON 
University of California Press, one of the most distinguished university presses in the United States, enriches lives around the world by advancing scholarship in the humanities, social sciences, and natural sciences. Its activities are supported by the UC Press Foundation and by philanthropic contributions from individuals and institutions. For more information, visit www.ucpress.edu.

This book is an independent work of scholarship. It is based on the author's own research, which included interviews with many of the artists, writers, and business people who participated in the making of The Lord of the Rings motion pictures and related projects. The author has attempted to verify the factual accuracy of the information presented here; nothing is made up or imagined. Many people involved with The Lord of the Rings motion pictures have assisted the author's research on this book by providing information and materials to her. However, no person or entity associated with the producers of The Lord of the Rings motion pictures has sponsored the research or writing of the book or endorsed the final product.

University of California Press

Berkeley and Los Angeles, California

University of California Press, Ltd.

London, England

(C) 2007 by The Regents of the University of California

Some of the topics in this volume appeared in "Fantasy, Franchises, and Frodo Baggins: The Lord of the Rings and Modern Hollywood," in The Velvet Light Trap 52 (Fall 2003): 45-63, published by the University of Texas Press.

An early version of the discussion of the buildup of the filmmaking infrastructure in Wellington was delivered as a paper at a symposium in Bremen and subsequently published in German in the proceedings of the symposium, as follows: "Hollywood, Wellywood und Peter Jackson," in Experiment Mainstream? Differenz und Uniformierung im Popularen Kino, ed. Imbert Schenk et al. (Berlin: Bertz + Fischer, 2006), 85-96.

Library of Congress Cataloging-in-Publication Data

Thompson, Kristin, 1950-

The Frodo franchise : The Lord of the Rings and modern Hollywood / Kristin Thompson. p. $\mathrm{cm}$.

Includes bibliographical references and index. ISBN: 978-0-520-24774-I (cloth : alk. paper)

I. Lord of the Rings films-History and criticism. I. Title.

PNI995.9.L58T46 2007

791.43'75-dc22 2007000109

Manufactured in the United States of America

$\begin{array}{llllllllll}\text { I6 } & \text { I5 } & \text { I4 } & \text { I3 } & \text { I2 } & \text { II } & \text { IO } & 09 & 08 & 07\end{array}$

$\begin{array}{llllllllll}\text { IO } & 9 & 8 & 7 & 6 & 5 & 4 & 3 & 2 & \text { I }\end{array}$

The paper used in this publication meets the minimum requirements of ANSI/NISO Z39.48-1992 (R 1997) (Permanence of Paper). 
For Barrie Osborne,

who trusted me and thus made this book possible 

This is just the overture, as the sweeping arms of popular culture embrace the Professor and his works.

CLIFF BROADWAY (QUiCKBEAM)

TheOneRing.net, 2001 
